\title{
The Functioning of the Regional Airport on the Example of Lublin Airport
}

\author{
Aleksander Nieoczym ${ }^{1,},{ }^{*}$ Jacek Caban ${ }^{2}$, and Ladislav Bartuška ${ }^{3}$ \\ ${ }^{1}$ Lublin University of Technology, Faculty of Mechanical Engineering, Nadbystrzycka 36, 20-618, \\ Lublin, Poland \\ ${ }^{2}$ University of Life Sciences in Lublin, Faculty of Production Engineering, Głęboka 28, 20-612 \\ Lublin, Poland \\ ${ }^{3}$ Institute of Technology and Business in České Budějovice, Faculty of Technology, Okružní 517/10, \\ 37001 České Budějovice, Czech Republic
}

\begin{abstract}
Transport accessibility of the region is one of the factors that intensify its development. The airport is a special example of transport point infrastructure, the presence of which in the region generates numerous benefits, both indirect and direct for users, among others reducing time and reducing travel costs. The article presents the characteristics of the airport in Lublin, and its communication system with the city, facilitating the flow of passengers and goods. Data on the operational activity of Lublin Airport were also presented.
\end{abstract}

\section{Introduction}

Transport infrastructure stimulates the development of the entire economy and creates conditions for its proper development. Transport accessibility of the region is one of the factors that intensify its development. The airport is a special example of transport point infrastructure, the presence of which in the region generates numerous benefits, both indirect and direct for users, among others reducing time and reducing travel costs. On the one hand, it enables technical support for aircraft during take-offs and landings, providing access to runways, taxiways, passenger and goods terminals as well as hangars. On the other hand, it is an intermodal knot that combines surface and air transport.

Integration of the airport with ground transport is important because it increases the accessibility of the airport and enables more inhabitants of the region to use the services of the port and air carriers. In addition, the close integration of the port with the system of expressways and rail transport is important for the development of freight transport. In the literature you can find a lot of research [1-6,], in which the issues of various transport systems in urban agglomerations are discussed.

The selection of an airport and the choice of a means of transport enabling the passenger to reach the airport is a complex decision-making process for passengers [7, 8]. The passenger is mobile, so they are looking for the most attractive connections in a certain geographical area, where they often have several airports to choose from. The passenger's

* Corresponding author: a.nieoczym@pollub.pl 
decision about the means of transport is largely dictated by qualitative characteristics. The most important criteria that the passenger is guided by can include [2, 7-10]:

- frequency of connections,

- hours and availability of flights,

- the price and amount of other travel-related fees,

- image of the carrier (reliability, punctuality, security),

- costs related to access to the airport, e.g. the amount of parking fees.

Time, price and convenience are for the passenger the most important criteria for choosing a means of transport [4, 11]. The construction of an attractive network of connections in cooperation with relevant carriers is therefore a basic challenge for airports that want to attract passengers' interest in their offer. Bearing in mind the above conclusions and the criterion of choosing a means of transport according to the "price-time" model, it should be recognized that in the long-term the development of demand for air transport services is largely conditioned by the availability of intermodal connections and integration with the local transport system. Increasingly, airports are connected to the urban agglomeration both by road and rail.

There are four levels of airport integration with the regional transport network [12]:

- the highest level - the airport is integrated with the motorway junction, and its highspeed railway station is located (an example of such a port is Frankfurt Main, Paris Charles de Gaulle),

- the airport is integrated with the rail network at regional level and with the expressway network (Amsterdam Schiphol, London Heathrow),

- the airport is connected to highways and has a local railway connection to the city served (Krakow Balice),

- the airport has a road connection that is not a high-speed road (airports in Poland outside Krakow-Balice).

The next part of the article will analyse the functioning of the Lublin Airport, which can be qualified for the third level of integration.

\section{Technical characteristics of the Lublin Airport}

Lublin Airport (IATA code: LUZ, ICAO code: EPLB) (Fig. 1) is located approximately 15 $\mathrm{km}$ from the center of Lublin.

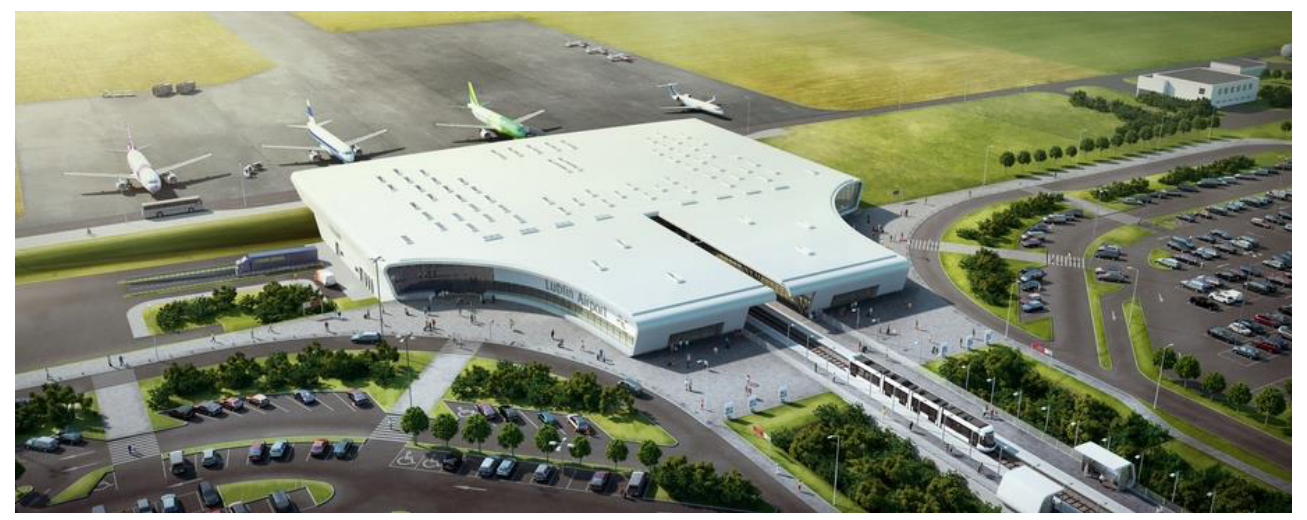

Fig. 1. Lublin Airport. Source: [13] 
Airport Lublin is currently the youngest passenger airport in the country. It covers approx. 250 ha and has a runway with a total length of $2.5 \mathrm{~km}$. Its construction began in autumn 2010 and was completed at the end of 2012. On December 12, 2012, the Airport in Lublin received a public use airport certificate. The most important operating data $[14,15]$ : IATA code: LUZ, ICAO code: EPLB

- Geographical location: latitude $-51^{\circ} 14^{\prime} 25^{\prime \prime} \mathrm{N}$, length - 22॰42’49” E.

- Runway: length 2,520 m, width $45 \mathrm{~m}$ :

- RWY $25257,07^{\circ} \mathrm{GEO}$ Asphalt PCN-50/F/B/W/T,

- RWY $07077,07^{\circ}$ GEO Asphalt PCN-50/F/B/W/T.

- At the threshold of 25 there is a place for returning airplanes.

- Navigation:

- D-VOR/DME, PAPI (in the direction of 07 and 25),

- ILS category II in the RWY 25 direction.

- Airport navigation lights:

- RWY 25 ALPA-ATA category II,

- RWY 07 - simplified light approach system.

- Aircraft parking plate with designated positions enabling setting:

- two aircraft of the D code and three aircraft of the $\mathrm{C}$ code, or

- one aircraft code D and 5 aircraft code C,

- one of the parking spaces of the D-code acts as a de-icing board in winter conditions.

Fire protection - category 7 .

\section{Communication connections with the airport}

One of the great advantages of the Lublin Airport is its central geographical location in relation to all cities in the Region (Figure 2).

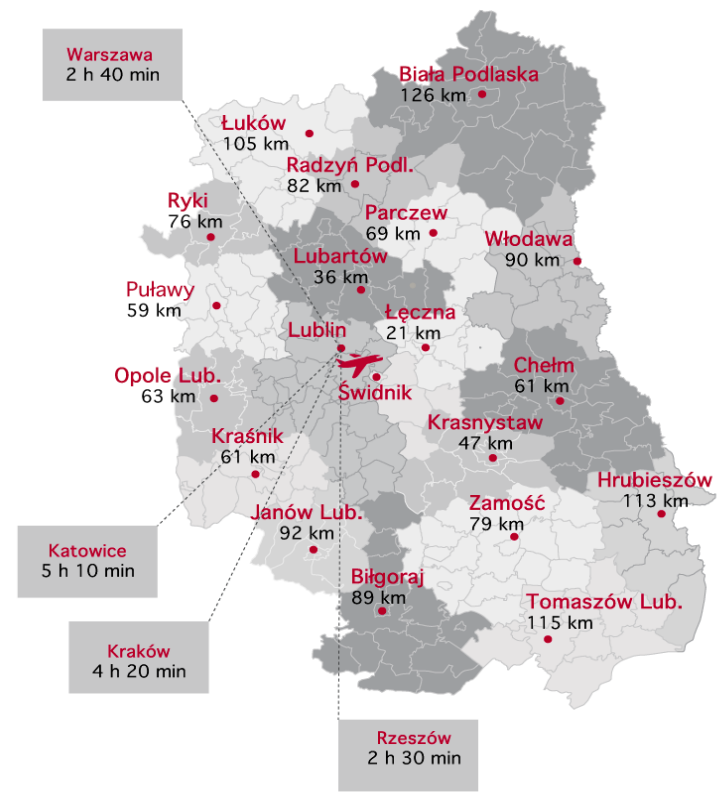

Fig. 2. Geographical location of Lublin Airport in the Region and journey time from near big cities with airport. Source: [13] 
Along with the construction of the Airport, the road and rail infrastructure was developed to ensure communication with the airport. Currently, access to the airport is provided by provincial road No. 822 and express road S-17 Warsaw - Hrebenne. In addition, for the needs of the airport, a new electrified railway line No. 581 was built connecting Lublin Główny station with the Airport station adjacent to the terminal. It is serviced by EN57AL electric traction units.

It should also be emphasized that the district of Świdnica runs important national and international routes, i.e. the international route (E 372) Warsaw - Kiev and the route (E 373) Warsaw - Kiev, as well as numerous, important sections of voivodship and district roads forming the communication openness of the whole the district area in all directions. Very important for the entire district and district centre is the location by the railway line connecting Lublin and Świdnik with Warsaw, and by Dęblin and Radom also with the western part of the country. To the east, this line connects Lublin with Kiev and Lvov.

One of the easiest ways to reach the airport is a bus, which leaves the Main Railway Station in Lublin. The bus is running regularly six times a day, the journey takes about a quarter of an hour, and tickets can be bought from the conductor [16]. The bus terminus is located in the terminal and is the only such solution in Poland.

The airport has a bus connection from Lublin and the cities of the region. These lines are operated by the following carriers:

- Garden Service provides direct bus services from Tomaszów Lubelski, Zamość and Krasnystaw.

- Galicja Express - offers direct journeys from Polańczyk, Sanok, Rzeszów and Janów Lubelski directly to the Lublin Airport.

- 24.pl transports provide direct bus services to / from Lublin from / to Lublin Airport

- Bus line 005 operated by the Public Transport Authority transports from the Centre of Lublin to / from the Airport. The bus drives up to the Departure Hall, while departures take place from the Arrivals Hall. Tickets are available from the bus driver.

Connections of selected cities of the region with Lublin Airport are presented graphically in Figure 3.

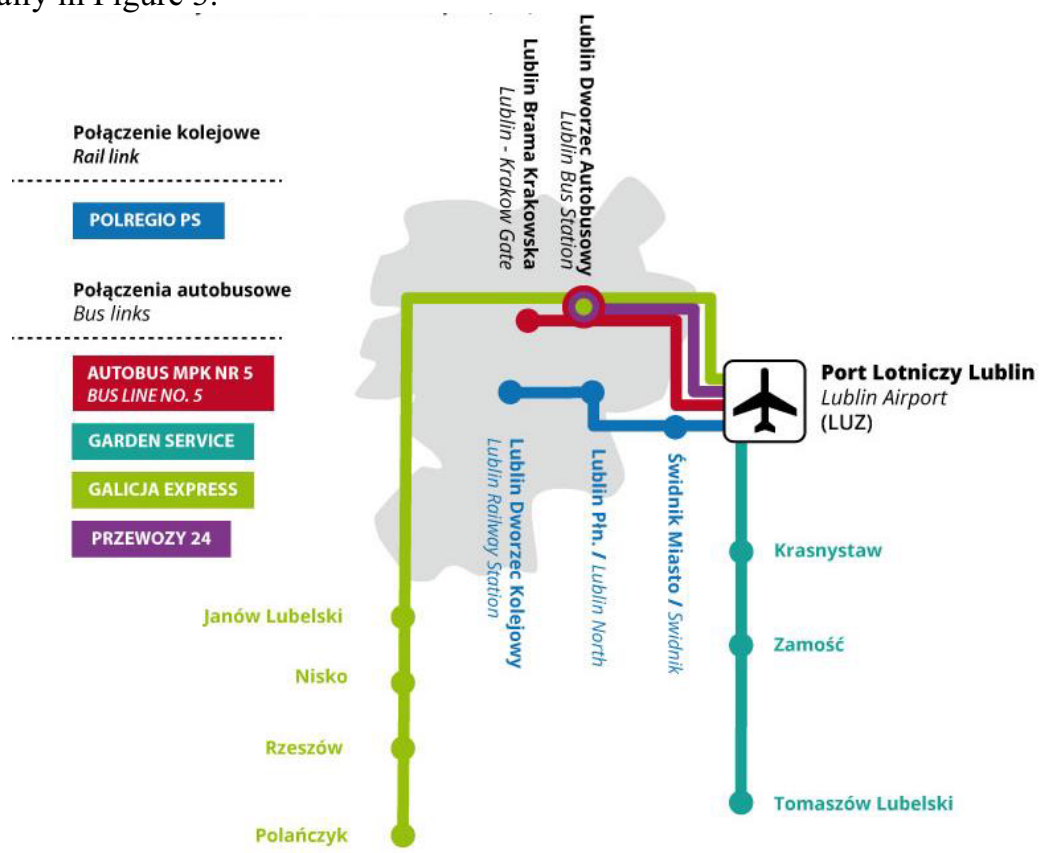

Fig. 3. Bus and railway connections to Lublin Airport. Source: [13] 
Passengers arriving by own car have two routes to choose from: the route leading through the S17 road and the voivodship road No. 822 .

For those using their own car, the Lublin Airport has two car parks with a total capacity of 450 seats (Figure 4 ).

Parking A - daily, is located in front of the entrance to the departure hall and is intended for long-term parking. Passengers can leave their car at Park A using a weekly package (80 PLN) or a two-week package (100 PLN).

Parking B - hourly, is located in front of the entrance to the arrivals hall and is intended for short-term parking.

Each parking lot has a "fast delivery / quick transfer" bay with free parking for up to 10 minutes. Payment for parking is made at self-service ticket offices located inside the terminal and at the terminal exits.

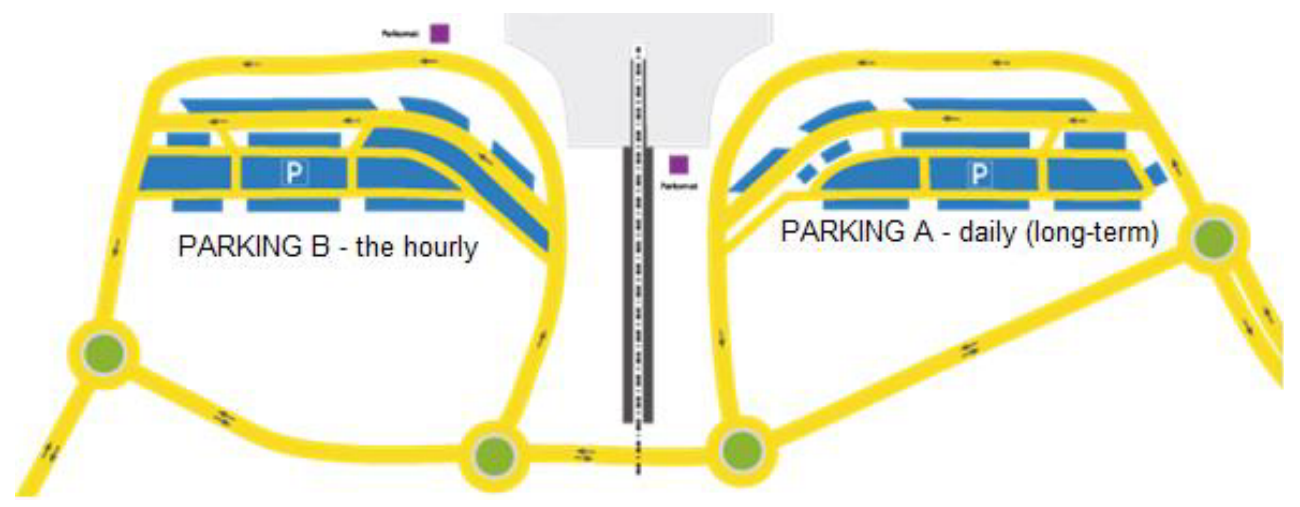

Fig. 4. Location of parking lots in front of the airport terminal. Source: [13]

Another type of transport to the airport from the centre of Lublin is by taxi. The biggest downside is the cost, which is about PLN 50. TAXI service in the field of individual passenger transport is provided by the Damel TAXI and iTAXI taxi company recommended by the Lublin Airport. There is no traditional taxi rank in front of the terminal building. A passenger who wants to leave the airport with a taxi of the recommended corporation should report to the terminal desk. Only cars belonging to the corporations selected in the competition and taxis which have been ordered individually by passengers are admitted to the airport area. The latter, just for a moment, come to the terminal to take passengers. However, they cannot wait for potential customers. The selection of the recommended corporation by the Lublin Airport guarantees a fixed price per kilometre.

A summary of the costs of getting to the airport from the centre of Lublin is given in Table. 
Table 1. List of the type and costs of transport from the city centre to Lublin Airport. Source: own study

\begin{tabular}{|c|c|c|c|}
\hline $\begin{array}{c}\text { Means of } \\
\text { transport }\end{array}$ & $\begin{array}{c}\text { Journey time } \\
{[\mathbf{m i n}]}\end{array}$ & $\begin{array}{c}\text { Price of journey } \\
{[\text { PLN] }}\end{array}$ & $\begin{array}{c}\text { Price of journey } \\
{[\mathbf{\epsilon}]}\end{array}$ \\
\hline Auto bus & 35 & 8 & 1.85 \\
\hline Rail & 15 & 5.3 & 1.25 \\
\hline Car & 25 & 10 & 2.35 \\
\hline Taxi & 25 & 50 & 11.65 \\
\hline
\end{tabular}

\section{Operating activity of Lublin Airport}

The airport is served mainly by low cost airlines Wizz Air, Ryanair, Carpatair, Eurolot. The only scheduled carriers are LOT and Lufthansa. The network of connections shown in Figure 5 was created at the beginning of 2015 as a result of agreements with the above carriers. In addition, from May 2015, the temporary opening of the Lublin - Stockholm Skavsta line operated by Wizz Air has been planned. Detailed information about carriers and serviced lines is provided in Table 2.

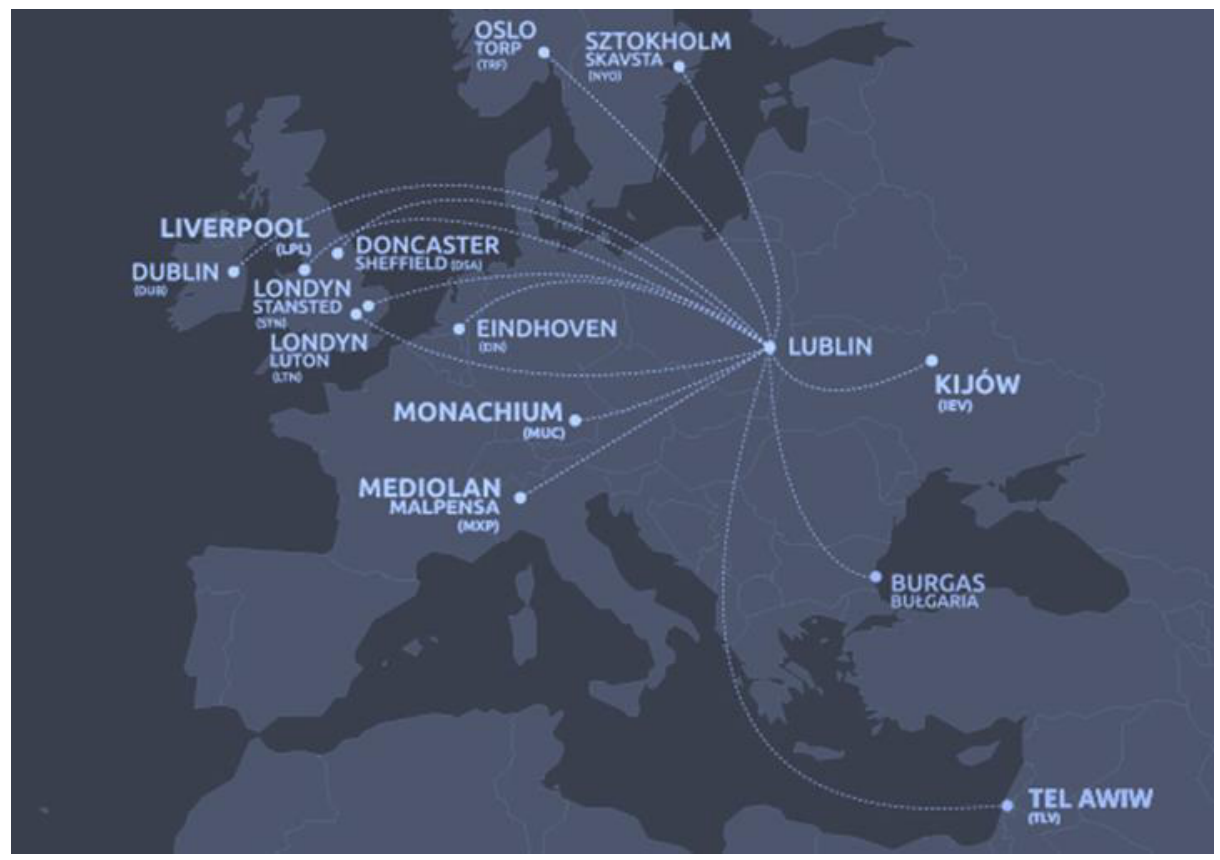

Fig. 5. Scheme of air connections from Lublin Airport. Source: [17] 
Table 2. Connections of Lublin Airport. Source: own study based on [13]

\begin{tabular}{|c|l|}
\hline Carier & \multicolumn{1}{|c|}{ Destination port } \\
\hline & $\begin{array}{l}\text { Doncaster Shelfield } \\
\text { Eindhoven } \\
\text { Kijev } \\
\text { Liverpool John Lenon } \\
\text { London Luton } \\
\text { Oslo Sandefjord } \\
\text { Stockholm Skavste } \\
\text { Tel Aviv }\end{array}$ \\
\hline Wizz Air & $\begin{array}{l}\text { Dublin } \\
\text { London Stansted }\end{array}$ \\
\hline Rynair & Tel Aviv \\
\hline LOT & Burgas \\
\hline Small Planet & Milan Malpensa \\
\hline easyJet & Munich \\
\hline flybmi.com & Munich \\
\hline BMI Regional Lufthansa &
\end{tabular}

In addition, Lublin Airport serves about 60 private flights a month. Airplanes from all Polish airports come to Świdnik, there are also international courses. The most flights were recorded from France, Switzerland and Russia. The list also includes: Germany, Sweden, Finland, Ukraine, Great Britain, Portugal, Spain, Italy, Greece, Israel, Denmark, Lithuania, Romania, Bulgaria, and even the USA and Australia.

The current disadvantage of the airport is that it is not available $24 / 7$. There is also no permanent flight control or permanent border crossing. The controllers are employed by the Polish Air Navigation Services Agency (PANSA), which sends them to Lublin only for 48 hours during the week. According to PANSA, 24 operations per week (referring to scheduled flights operated by airlines) are enough. For a long time, the authorities of the Lublin airport have been applying for permanent inspections, but PANSA makes this condition dependent on a larger number of regular flights.

The number of air operations and the volume of passenger traffic are shown in Figure 68.

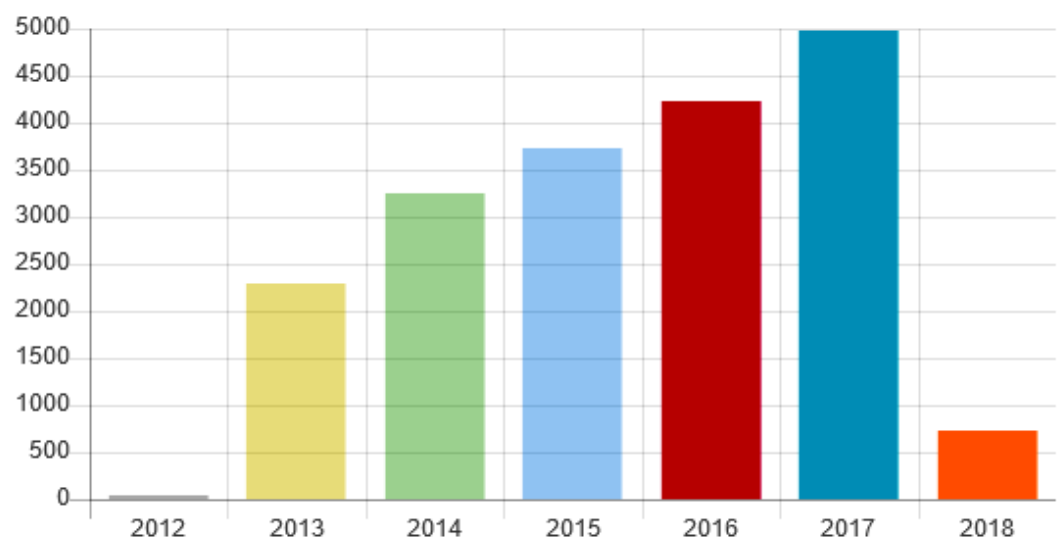

Fig. 6. Number of air operations at the Lublin Airport in years 2012 - Q1 2018. Source: [13] 


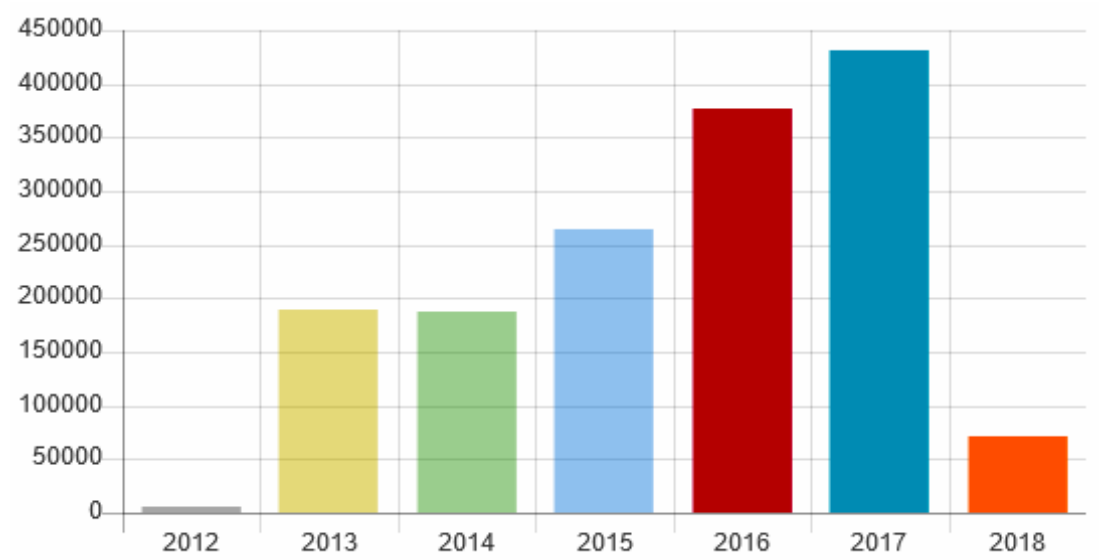

Fig. 7. Passenger traffic at the Lublin Airport in the years 2012 - Q1 2018. Source: [13]

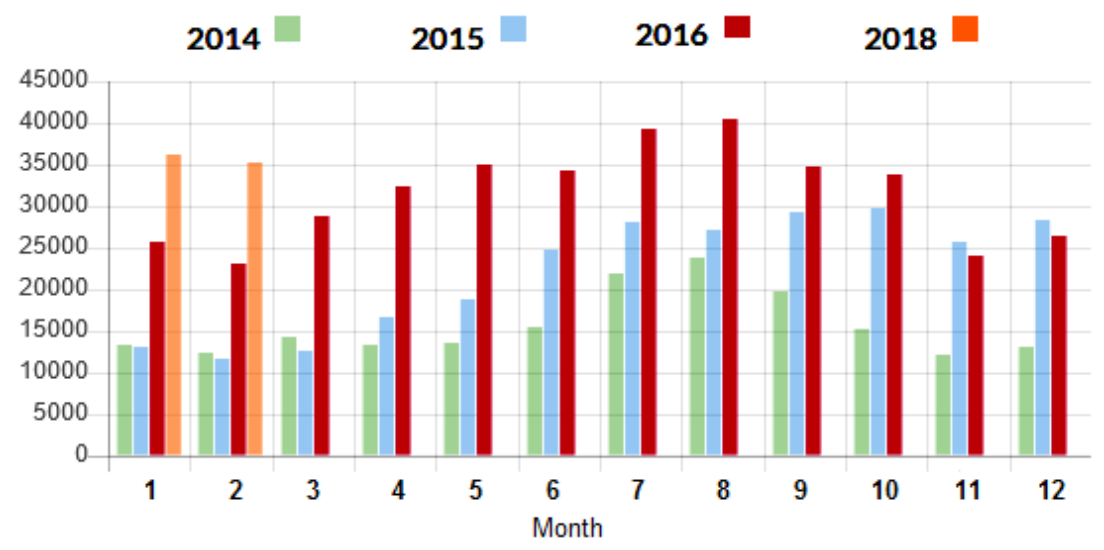

Fig. 8. Passenger traffic at the Lublin Airport in particular months in 2014 - Q1 2018. Source: [13]

According to PLL experts, the regional airport will start to make money after about seven years of being put into service. Airports, by their very idea, are not only companies that are only supposed to earn money. The benefits of the airport are much greater than the accounting numbers after the first year of operation. It saves time during travel, increases the mobility of society, a window that connects the region with the world. In addition, companies that have invested in Lublin and the surrounding area due to the airport have to be added. This was confirmed, for example, by the German manufacturer of electric motors with the ABM Greiffenberger factory in the Special Economic Zone in Lublin [18]. The municipal department of the investment after the first year of operation of the airport received 50 percent more investment inquiries than in previous years [18].

\section{Conclusions}

The dynamic development of the air transport services sector in the world in the second half of the 20th century has made airports an indispensable element of transport infrastructure and one of the symbols of modern economy. The decision on the construction of airport terminals and transfer points should take into account their location, so that disturbances in the course of the integrated transport chain are minimal. In addition, the experience of European hubs shows that means of air and rail transport can work together to create 
efficient transport solutions. In the case of regional airports in Poland, only the airport in Krakow and, recently, in Lublin has a rail connection with the agglomeration.

Road and rail infrastructure on the one hand is an unquestionable advantage for airports as it makes it easier for passengers to reach their destination quickly. On the other hand, high speed railways and highways are also a threat to a given airport because they not only provide substitute services for air transport but also facilitate access to competing airports. As the time needed for commuting decreases, the zones of impact of particular ports start to overlap, thanks to which passengers have more airports to choose from. It can therefore be concluded that the progressive development of rail connections, express roads and motorways contributes to increasing competition in the air services market.

\section{References}

1. E. Brumercikova, B. Bukova, P. Kondek, 18th International Scientific ConferenceLOGI 2017, MATEC Web of Conferences, 134 (2017)

2. M. Jaśkiewicz, G. Koralewski, J. Stokłosa, XI International Science-Technical Conference Automotive Safety 2018, IEEE Proceedings Paper, (2018)

3. J. Lizbetin, O. Stopka, Proceedings Of The Third International Conference On Traffic And Transport Engineering (ICTTE), (2016)

4. M. Poliak, A. Poliakova, M. Mrnikova, P. Simurkova, M. Jaśkiewicz, R. Jurecki, Journal of Competitiveness, 9, 3 (2017)

5. T. Skrucany, M. Kendra, M. Skorupa, J. Grencik, T. Figlus, 12th International Scientific Conference of Young Scientists on Sustainable, Modern and Safe Transport, Procedia Engineering, 192 (2017)

6. O. Stopka, M. Chovancova, R. Kampf, 18th International Scientific Conference-LOGI 2017, MATEC Web of Conferences, 134 (2017)

7. Albers S., Koch B., Ruff Ch., J. Air Transp. Manag. 11 (2005)

8. Augustyniak W. M., Efektywność polskich regionalnych portów lotniczych, $\mathrm{PhD}$ Thessis, Poznań 2012.

9. Graham A., Managing Airports, An International Perspective, (Elsevier, Third edition, Oxford, 2008)

10. L. Ližbetinová, M. Hitka, C. Li, Z. Caha, MATEC Web of Conferences, 134, art. no. 00032, DOI: 10.1051/matecconf/201713400032 (2017)

11. O. Stopka, R. Kampf, J. Lizbetin, M. Hlatka. 16th International Scientific Conference Proceedings, PTS I-V, (2016)

12. Ministerstwo Transportu, Program rozwoju sieci lotnisk i lotniczych urządzeń naziemnych, (Warsaw 2007)

13. www.airport.lublin.pl

14. http://www.pansa.pl/

15. http://www.ulc.gov.pl/

16. R. Kampf, O. Stopka, I. Kubasakova, V. Zitricky. Wmcaus 2016. DOI: 10.1016/j.proeng.2016.08.623 (2016)

17. www.prtl.pl

18. http://lublin.gazeta.pl/lublin/1,48724,16209857

19. R. Kampf, S. Lorincova, M. Hitka, O. Stopka. Sustainability, 9. DOI: $10.3390 /$ su9091561 (2017) 